\title{
SHEAR LAG FACTORS FOR TENSION ANGLES WITH UNEQUAL-LENGTH LONGITUDINAL WELDS
}

\author{
J. Kent Hsiao ${ }^{1, *}$ and Saurav Shrestha ${ }^{2}$ \\ ${ }^{1}$ Professor, Department of Civil and Environmental Engineering, \\ Southern Illinois University Carbondale, Carbondale, IL, USA \\ ${ }^{2}$ Former Graduate Student, Department of Civil and Environmental Engineering, \\ Southern Illinois University Carbondale, Carbondale, IL, USA \\ *(Corresponding author: Email: hsiao@engr.siu.edu)
}

Received: 18 June 2017; Revised: 18 June 2017; Accepted: 19 October 2017

\begin{abstract}
When a tension load is transmitted to some, but not all of the cross-sectional elements of a tension member, the tensile force is not uniformly distributed over the cross-sectional area of the tension member. The non-uniform stress distribution in the tension member is commonly referred to as the out-of-plane shear lag effect. The unequal-length longitudinal welds and the in-plane shear lag effect, however, are not addressed by the current American Institute of Steel Construction (AISC) Specification for the determination of the shear lag factors for tension members other than plates and Hollow Structural Sections (HSS). The purpose of this work is to propose a procedure for the computation of shear lag factors accounting for combined in-plane and out-of-plane shear lag effects on unequal-length longitudinal welded angles. The finite element method using three-dimensional solid elements and nonlinear static analyses accounting for combined material and geometric nonlinearities are conducted in this work to verify the accuracy of the proposed procedure.
\end{abstract}

Keywords: Angle sections, connections, finite element method, geometric nonlinearity, nonlinear analysis, shear lag, stress distribution, welds

DOI: $10.18057 /$ IJASC.2018.14.4

\section{INTRODUCTION}

The provisions regarding shear lag effects in bolted tension members appeared in the 1978 American Institute of Steel Construction (AISC) Specification (Easterling and Gonzalez [1]; AISC [2]). The 1986 and 1989 AISC Specifications have extended the provisions to welded tension members (AISC [3]; AISC [4]). The 1993 and 1999 AISC Specifications expressed the shear lag provisions using the formula $U=1-(\bar{x} / L) \leq 0.9$ for the tension load transmitted only by longitudinal welds to a tension member other than a plate member, where $U$ is the shear lag coefficient, $\bar{x}$ is the connection eccentricity, and $L$ is the length of the connection in the directions of loading (AISC [5]; AISC [6]). The upper limit of 0.9 has been removed in the 2005 and 2010 AISC Specifications (AISC [7]; AISC [8]).

The provisions specified in the current AISC Specification (AISC [8]) only address the out-of-plane shear lag effects for all tension members except plates while the in-plane shear lag effects have been neglected. When a tension load is transmitted to some, but not all of the cross-sectional elements of a tension member other than a plate member, the tensile force is not uniformly distributed over the cross-sectional area of the tension member. The non-uniform stress distribution in the tension member is commonly referred to as the out-of-plane shear lag effect.

Referring to the tension member shown in Figure 1, when the tension load is transmitted to some, but not all of the cross-sectional elements, the effective length of the welded connection is reduced to $L^{\prime}=L-\bar{x}$, where $\bar{x}$ is the connection eccentricity measured from the plane of the connection to 
the member centroid and $L$ is the length of the connection in the direction of loading. Since the reduction in the effective cross-sectional area is proportional to the reduction in the effective connection length, $L^{\prime} / L$, the out-of-plane shear lag factor becomes (Geschwindner [9]):

$U_{O E}=\frac{L^{\prime}}{L}=\frac{L-\bar{x}}{L}=1-\frac{\bar{x}}{L}$

Therefore, the value of the out-of-plane shear lag factor is influenced by the length of the connection and the geometry of the cross-section of the tension member.

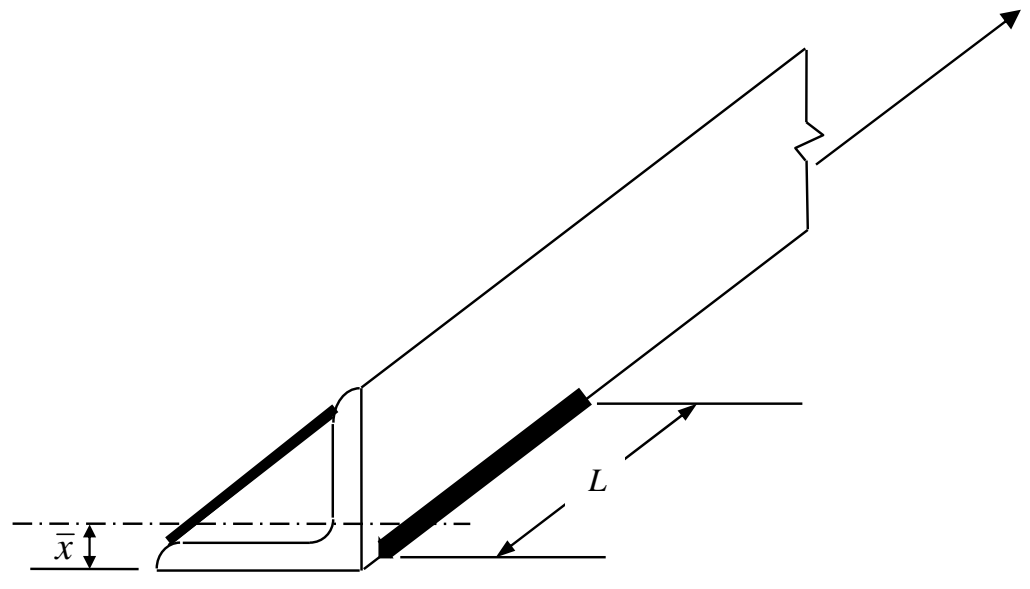

(a)

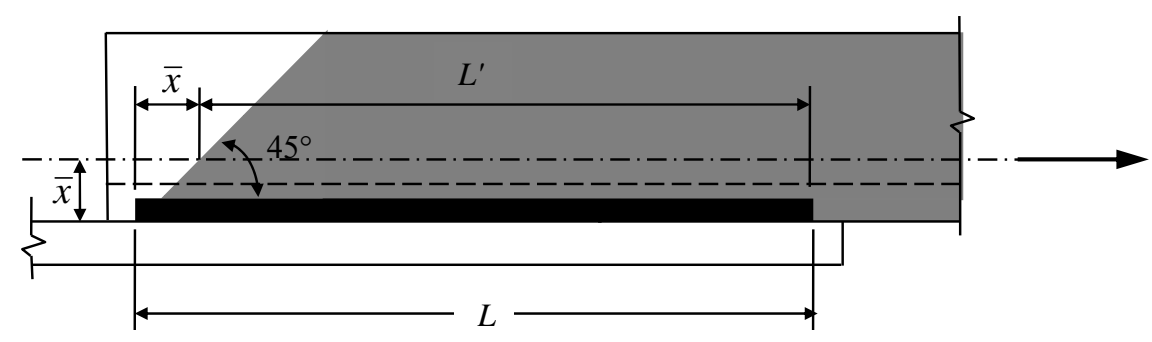

(b)

Figure 1. Out-of-Plane Shear Lag Effect on Welded Angle in Tension

In addition to the out-of-plane shear lag effect for unconnected (outstanding) element(s), the in-plane shear lag effect, $U_{C E}$, for connected element(s) was also recommended to be considered, as given in Eq. 2 (Fortney and Thornton [10]):

$U_{C E}=\frac{1}{1+\frac{1}{3}\left(\frac{w}{L}\right)^{2}}$

where $w=$ the distance between longitudinal welds and $L=$ the length of weld.

The combined effect of the in-plane and out-of-plane shear lags can be approximately determined as the product of the two component effects as given in Eq. 3 (Fortney and Thornton [10]): 
$U=U_{C E} U_{O E}=\left(\frac{1}{1+\frac{1}{3}\left(\frac{w}{L}\right)^{2}}\right)\left(1-\frac{\bar{x}}{L}\right)$

\section{NEWLY PROPOSED PROCEDURE FOR THE COMPUTATION OF SHEAR LAG FACTORS}

The following addresses a new computation procedure for shear lag factors for tension angles with unequal-length longitudinal fillet welds. Referring to Figure 2, when the width of the welded leg is shorter than the indented distance of the short weld length, [that is, $w \leq\left(L_{1}-L_{2}\right) / 2$ ], the out-of-plane shear lag effect on the out-of-plane leg can also be applied to the in-plane leg. Therefore, the in-plane shear lag effect, $U_{C E}$, for the connected leg can be computed using Eq. 4:

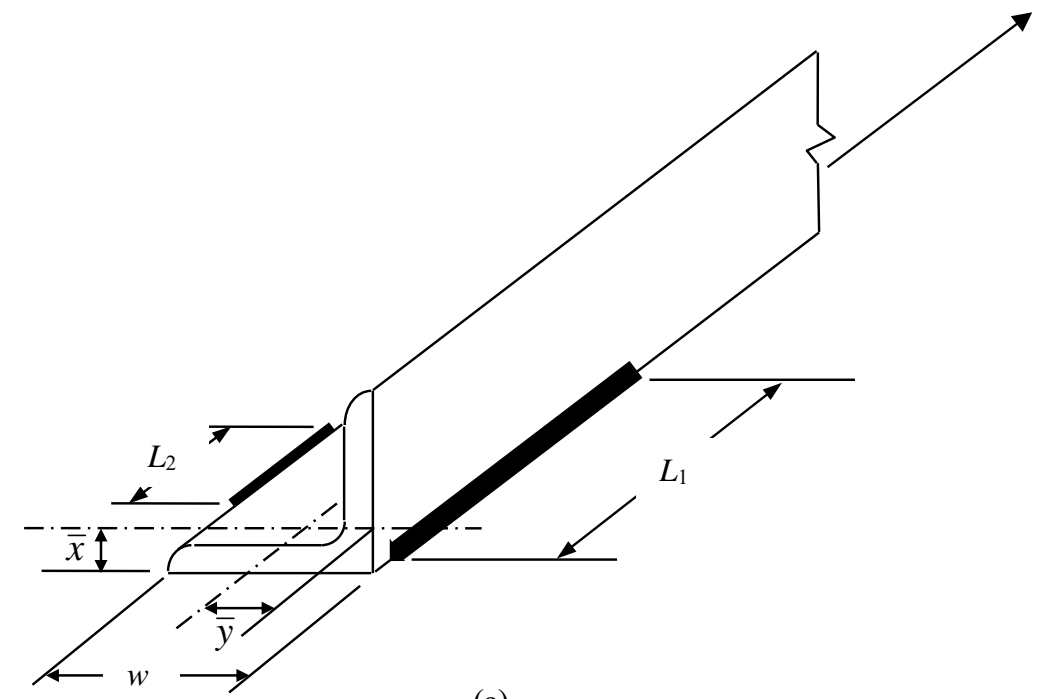

(a)

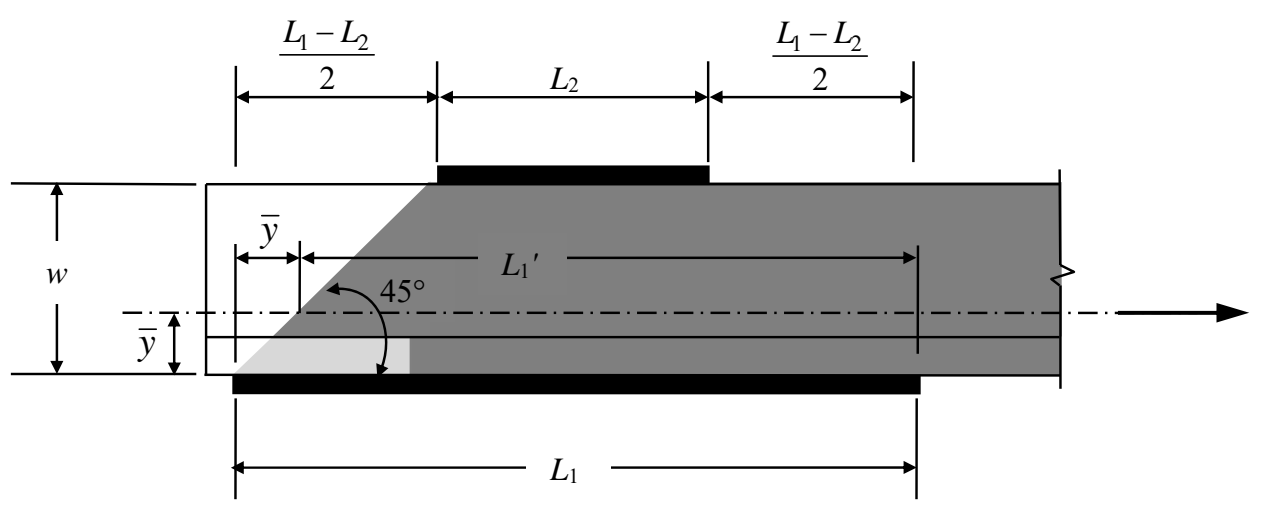

(b)

Figure 2. In-Plane Shear Lag Effect on a Tension Angle with Unequal-Length Welds

$U_{C E}=\frac{L_{1}^{\prime}}{L_{1}}=\frac{L_{1}-\bar{y}}{L_{1}}=1-\frac{\bar{y}}{L_{1}}$ 
The combined effect of the in-plane and out-of-plane shear lags can be approximately determined as the product of the two component effects, as given in Eq. 5:

$U=U_{C E} U_{O E}=\left(1-\frac{\bar{y}}{L_{1}}\right)\left(1-\frac{\bar{x}}{L_{1}}\right)$

where $\bar{x}=$ the distance from the outer face of the connected leg to the centroid of the angle; $\bar{y}=$ the distance from the outer face of the outstanding leg to the centroid of the angle; and $L_{1}=$ the length of the longer weld.

\section{DESIGN PROCEDURE FOR A TENSION MEMBER TO A GUSSET PLATE CONNECTION}

The following are the recommended criteria to be used for the design of a tension member to a gusset plate connection (Astaneh-As1 [11]) using longitudinal fillet welds:

(1) The capacity of the welded connection is recommended to be at least equal to or greater than the axial tension yield capacity of the tension member calculated using a conservative expected yield stress of $1.1 R_{y} F_{y}$ in order to avoid brittle failure of the connections, where $R_{y}$ is the ratio of the expected yield strength to the specified minimum yield strength of the grade of steel to be used $\left[R_{y}=1.5\right.$ for ASTM A36 steel channels (AISC [12])] and $F_{y}$ is the specified minimum yield strength of the grade of steel to be used.

(2) The yielding of the tension member shall occur before the yielding of the gusset plate in order to increase the global ductility of the entire frame:

$$
R_{y} F_{y} A_{g} \leq F_{y} A_{e}
$$

where $A_{g}$ is the cross-sectional area of the tension member and $A_{e}$ is the area of the Whitmore effective section of the gusset plate.

(3) The design tensile strength for the tensile rupture in the net section of the tension member is recommended to be computed using the following equation (AISC [8]):

$\phi_{t} P_{n}=\phi_{t} F_{u} A_{n} U$

where $\phi_{t}=0.75 ; P_{n}=$ nominal tensile strength of the tension member; $F_{u}=$ specified minimum tensile strength of the type of steel being used $\left[F_{u}=58 \mathrm{ksi}(400 \mathrm{MPa})\right.$ for ASTM A36 steel]; $A_{n}=$ net area; and $U=$ shear lag factor. 


\section{DESIGN EXAMPLE OF THE LONGITUDINAL WELDS BALANCED ABOUT THE NEUTRAL AXIS OF AN ANGLE IN TENSION}

Use A36 steel, E70 electrodes to design the longitudinal side fillet welds to develop the full axial yield capacity of a $2 \mathrm{~L} 4 \times 3 \times 3 / 8$ LLBB (with long legs back-to-back) tension member connected to a gusset plate. Assume that the tension member is subjected to cyclic loading which results in repeated stress variations; therefore, it is preferable to use two longitudinal welds of unequal length to ensure the welds' centroid will coincide with the centroid of the member so that the transmitted tensile forces will be balanced about the neutral axis of the tension angle (AISC [8]).

\subsection{Design of the Unequal-Length Longitudinal Fillet Weld Connection to Balance the Tensile Forces about the Neutral Axis of the Tension Angle}

The full axial yield capacity of a $\mathrm{L} 4 \times 3 \times 3 / 8$ tension member can be computed as follows:

$$
1.1 R_{y} F_{y} A_{g}=1.1(1.5)(36 \mathrm{ksi})\left(2.49 \mathrm{in}^{2}\right)=147.9 \mathrm{kips}(658 \mathrm{kN})
$$

where $R_{y}=1.5$ and $F_{y}=36 \mathrm{ksi}(248 \mathrm{MPa})$ for A36 steel; $A_{g}=$ the gross area of the tension member.

Assume that the gusset plate is thicker than the angle. In this case, since the material thickness of the thinner part joined is $3 / 8$ in. $(10 \mathrm{~mm})$, the minimum weld size $=3 / 16$ in. ( $5 \mathrm{~mm}$ ) (AISC [8]). Also, since the thickness of the angle is $3 / 8$ in. $(10 \mathrm{~mm})$, the maximum weld size $=3 / 8-1 / 16=5 / 16$ in. $(8 \mathrm{~mm})$ (AISC [13]). With the minimum and maximum fillet weld sizes defined, one can use a size of $1 / 4$ in. (6 mm) for the fillet weld (since $3 / 16 \leq 1 / 4 \leq 5 / 16$, the weld size may be used). The design strength of the weld per inch can thus be computed as follows:

$\phi t_{e}\left(0.60 F_{E X X}\right)=0.75[(0.707)(1 / 4 \mathrm{in})].(0.60)(70 \mathrm{ksi})=5.568 \mathrm{kips} / \mathrm{in} .(0.975 \mathrm{kN} / \mathrm{mm})$

where $t_{e}=$ the effective throat of the fillet weld and $F_{E X X}=$ the tensile strength of the weld metal $\left(F_{E X X}=70 \mathrm{ksi}\right.$ for E70 electrodes $)$.

Therefore, the total required weld length can be computed as follows:

$L_{\text {total }}=\frac{147.9 \mathrm{kips}}{5.568 \mathrm{kips} / \mathrm{in} .}=26.56 \mathrm{in} .(675 \mathrm{~mm})$

Referring to Figure 3(a), taking the moment about point A to determine the force $P_{2}$ and $P_{1}$ :

$P_{2}(4$ in. $)=(147.9 \mathrm{kips})(1.27$ in. $)$

From which, $P_{2}=\frac{(147.9)(1.27)}{4}=47.0 \mathrm{kips}(209 \mathrm{kN})$, and $P_{1}=147.9-47.0=100.9 \mathrm{kips}(449 \mathrm{kN})$

Therefore, the required weld length on the outstanding leg side, $L_{1}$, and on the flat leg side, $L_{2}$, can be computed respectively as follows:

$$
L_{1}=\frac{100.9}{5.568}=18.12 \text { in. } \approx 18.5 \text { in. }(470 \mathrm{~mm})
$$


$L_{2}=\frac{47.0}{5.568}=8.44$ in. $\approx 8.5$ in. $(216 \mathrm{~mm})$

The connection details of the unequal-length longitudinal fillet welds for the angle are shown in Figure 3(b). Note that fillet weld terminations should be located approximately one weld size from the edge of the connection to minimize notches in the base metal (AISC [8]).

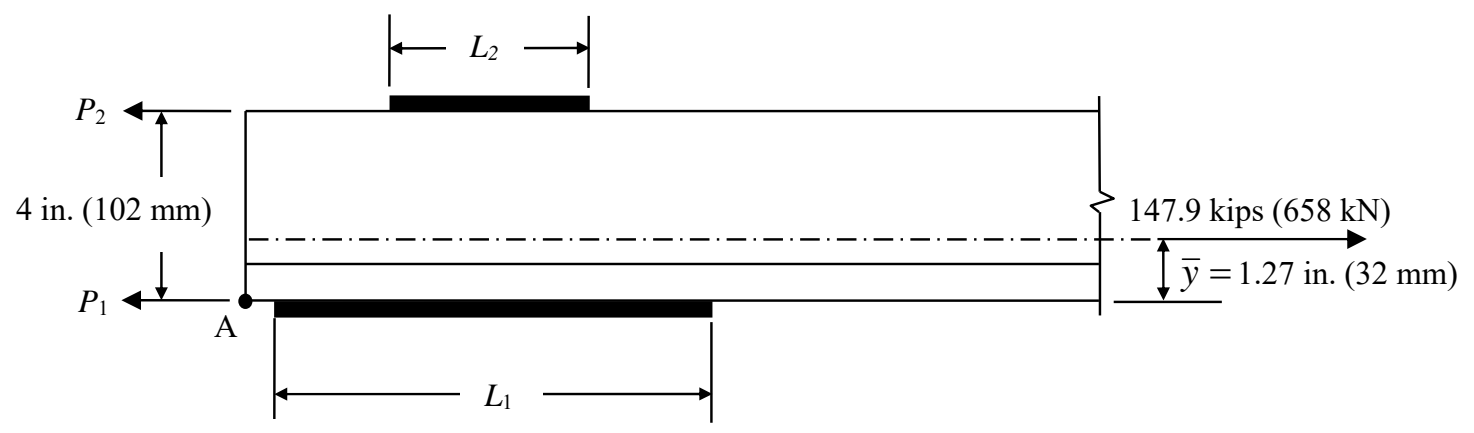

(a)

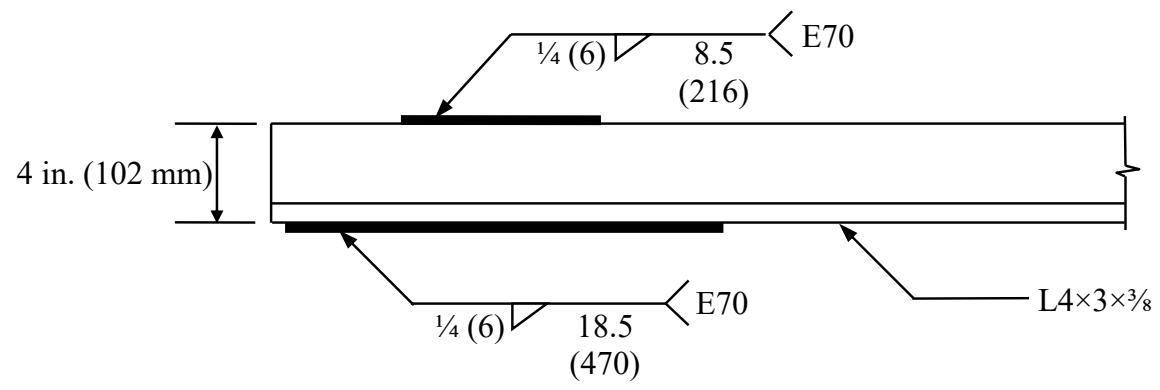

(b)

Figure 3. Unequal-Length Longitudinal Fillet Weld Connection for the $\mathrm{L} 4 \times 3 \times 3 / 8$ Tension Member

\subsection{Design of the Gusset Plate}

Using Eq. 6, one has:

$1.5(36 \mathrm{ksi})(2)\left(2.49 \mathrm{in}^{2}\right) \leq(36 \mathrm{ksi})\left(A_{e}\right)$

From which, the area of the Whitmore effective section, $A_{e}$, must be $\geq 7.47 \mathrm{in}^{2}\left(4819 \mathrm{~mm}^{2}\right)$.

Note that in order to avoid the out-of-plane eccentricity effect on the gusset plate (due to one angle being connected to one side of the gusset plate), two L $4 \times 3 \times 3 / 8$ angles, with long legs back-to-back, are used as the tension member for this design example.

Referring to Figures 3 and 4, the effective width of the Whitmore section (Whitmore [14]) can be computed to be:

$l_{w}=(8.5$ in. $)\left(\tan 30^{\circ}\right)+(18.5$ in. $)\left(\tan 30^{\circ}\right)+4$ in. $=19.59$ in. $(498 \mathrm{~mm})$

From which, the required thickness of the gusset plate can be computed to be: 
$t=\frac{A_{e}}{l_{w}}=\frac{7.47}{19.59}=0.381$ in. $\left[\right.$ use $^{7 / 16}$ in. $\left.(11 \mathrm{~mm})\right]$

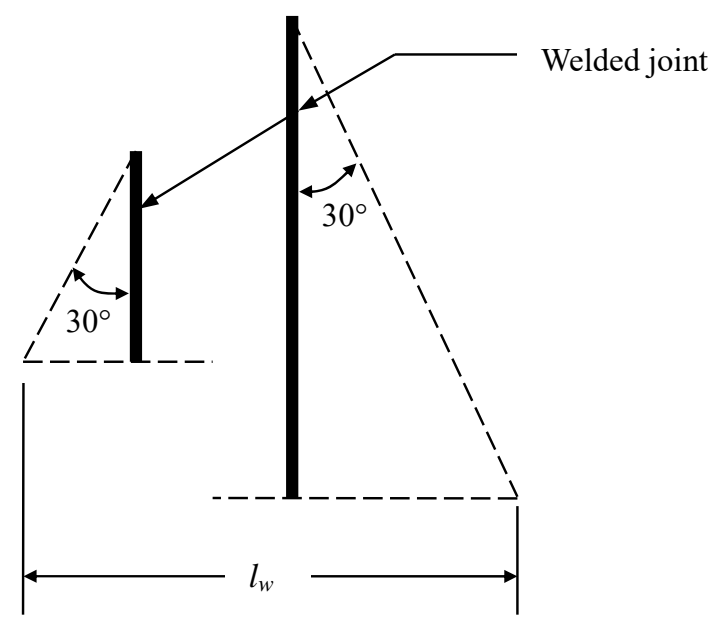

Figure 4. The Whitmore Section for Unequal-Length Welded Joints

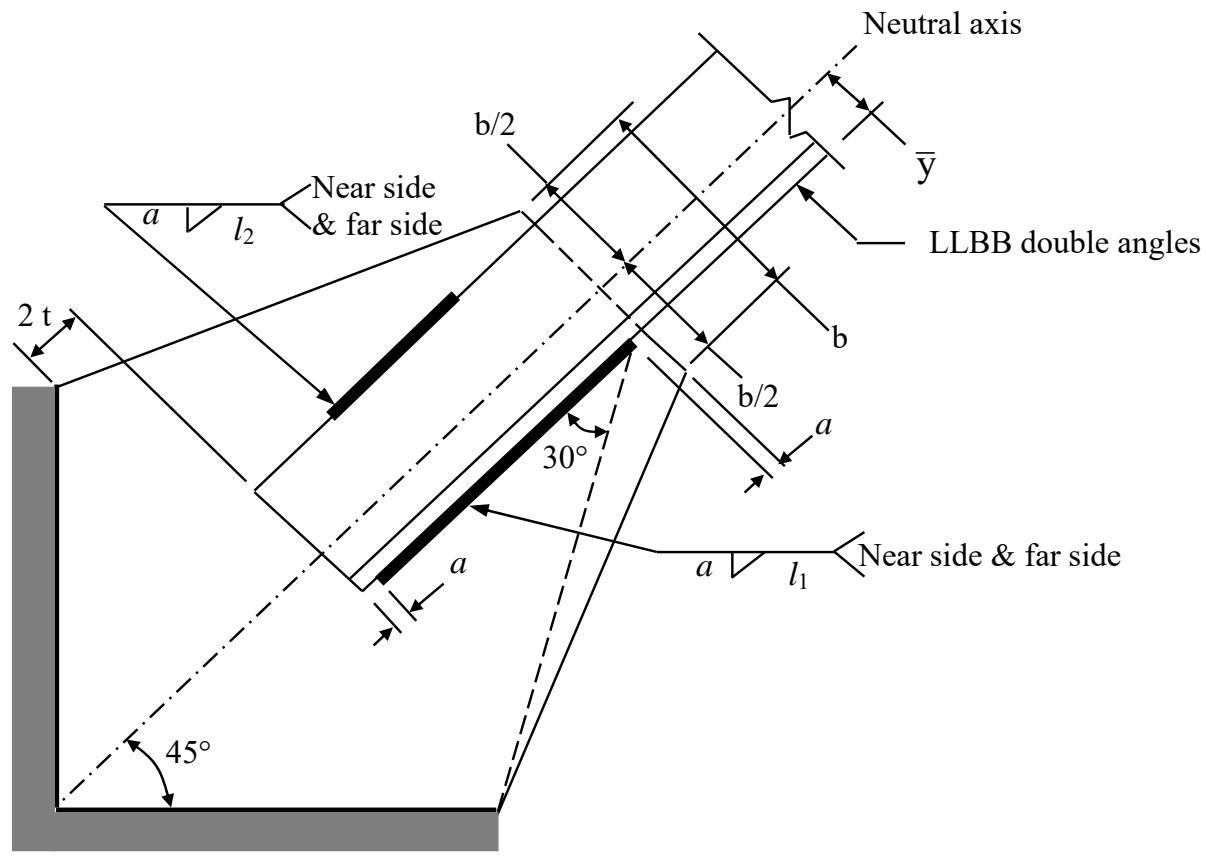

Notes: $\mathrm{t}=$ Plate thickness; $a=$ Weld size; $l_{1}=$ Long weld length; and $l_{2}=$ Short weld length

\begin{tabular}{|c|c|c|c|c|c|c|}
\hline $\begin{array}{c}\text { LLBB Double } \\
\text { Angles }\end{array}$ & $\begin{array}{c}\bar{y} \\
\text { in. } \\
(\mathrm{mm})\end{array}$ & $\begin{array}{c}\mathrm{b} \\
\text { in. } \\
(\mathrm{mm})\end{array}$ & $\begin{array}{c}\mathrm{t} \\
\text { in. } \\
(\mathrm{mm})\end{array}$ & $\begin{array}{c}a \\
\text { in. } \\
(\mathrm{mm})\end{array}$ & $\begin{array}{c}l_{1} \\
\text { in. } \\
(\mathrm{mm})\end{array}$ & $\begin{array}{c}l_{2} \\
\text { in. } \\
(\mathrm{mm})\end{array}$ \\
\hline $2 \mathrm{~L} 4 \times 3 \times 3 / 8$ & 1.27 & 6 & $7 / 16$ & $1 / 4$ & 18.5 & 8.5 \\
& $(32)$ & $(152)$ & $(11)$ & $(6)$ & $(470)$ & $(216)$ \\
\hline $2 \mathrm{~L} 6 \times 31 / 2 \times 3 / 8$ & 2.02 & 8 & $7 / 16$ & $1 / 4$ & 24.5 & 12.5 \\
& $(51)$ & $(203)$ & $(11)$ & $(6)$ & $(622)$ & $(318)$ \\
\hline $2 \mathrm{~L} 6 \times 4 \times 99 / 16$ & 2 & 8 & $5 / 8$ & $3 / 8$ & 25.5 & 13 \\
& $(51)$ & $(203)$ & $(16)$ & $(10)$ & $(648)$ & $(330)$ \\
\hline
\end{tabular}

Figure 5. Unequal-Length Longitudinal Fillet Weld Connection Details for Double Angles 
Following the procedure of this design example, the unequal-length longitudinal fillet weld connections for two additional double angles of different sizes $\left(2 \mathrm{~L} 6 \times 3 \frac{1}{2} \times 3 / 8\right.$ and $\left.2 \mathrm{~L} 6 \times 4 \times 9 / 16\right)$ are designed and summarized in Figure 5. Note that in order to ensure that the gusset plate can freely rotate when the double angles are subjected to compression forces, the distance from the end of the double angles to the line that connects the two re-entrant corners of the gusset plate is at least two times the thickness of the gusset plate (Astaneh-Asl [11]).

\section{COMPUTATION OF SHEAR LAG FACTORS FOR TENSION ANGLES WITH UNEQUAL-LENGTH LONGITUDINAL FILLET WELD CONNECTIONS}

\subsection{The AISC Procedure}

Since the unequal-length longitudinal welds and the in-plane shear lag effect are not addressed by the current AISC Specification (AISC [8]) for the determination of shear lag factors for tension members other than plates and Hollow Structural Sections (HSS), the following formula may be used for the computation of the $U$ value for the given example, $2 \mathrm{~L} 4 \times 3 \times 3 / 8$, shown in Figure 3 .

$U_{A I S C}=U_{O E}=1-\frac{\bar{x}}{L}$

The above formula results in three different $U$ values, depending upon which of the follow three $L$ values are used for this formula:

(1) For $L=l_{1}, U_{A I S C\left(l_{1}\right)}=1-\frac{\bar{x}}{l_{1}}=1-\frac{0.775}{18.5}=0.96$

(2) For $L=\frac{l_{1}+l_{2}}{2}, U_{\text {AISC (avg) }}=1-\frac{\bar{x}}{\left(\frac{l_{1}+l_{2}}{2}\right)}=1-\frac{0.775}{13.5}=0.94$

(3) For $L=l_{2}, U_{\operatorname{AISC}\left(l_{2}\right)}=1-\frac{\bar{x}}{l_{2}}=1-\frac{0.775}{8.5}=0.91$

Following the same procedure, the $U$ values for two additional double angles of different sizes $\left(2 \mathrm{~L} 6 \times 3 \frac{1}{2} \times 3 / 8\right.$ and $2 \mathrm{~L} 6 \times 4 \times 9 / 16$ shown in Figure 5) are computed. All the results are summarized in Table 1 .

\subsection{The Fortney and Thornton Procedure}

Fortney and Thornton [10] recommended that Eq. 3 be used for the computation of the $U$ values for angles with unequal-length longitudinal welds. Also, $L=\left(l_{1}+l_{2}\right) / 2$ was recommended to be used for this formula. Using Eq. 3, the $U$ value of the given example, $2 \mathrm{~L} 4 \times 3 \times 3 / 8$, shown in Figure 3, can be computed to be: 
$U_{F \& T}=\left(\frac{1}{1+\frac{1}{3}\left(\frac{w}{\left(\frac{l_{1}+l_{2}}{2}\right)}\right)^{2}}\right)\left(1-\frac{\bar{x}}{\left(\frac{l_{1}+l_{2}}{2}\right)}\right)=\left(\frac{1}{1+\frac{1}{3}\left(\frac{4}{13.5}\right)^{2}}\right)\left(1-\frac{0.775}{13.5}\right)=0.92$

Following the same procedure, the $U$ values for two additional double angles of different sizes $\left(2 \mathrm{~L} 6 \times 3 \frac{1}{2} \times 3 / 8\right.$ and $2 \mathrm{~L} 6 \times 4 \times 9 / 16$ shown in Figure 5) are computed. All the results are summarized in Table 2.

\subsection{The New Procedure Proposed in this Paper}

Eq. 5 is the newly proposed procedure that may also be used for the computation of the $U$ values for angles with unequal-length longitudinal welds. Using Eq. 5, the $U$ value of the given example, $2 \mathrm{~L} 4 \times 3 \times 3 / 8$, shown in Figure 3 [in which $w=4$ in. $\leq\left(L_{1}-L_{2}\right) / 2=5$ in.] can be computed to be:

$U_{N e w}=U_{C E} U_{O E}=\left(1-\frac{\bar{y}}{l_{1}}\right)\left(1-\frac{\bar{x}}{l_{1}}\right)=\left(1-\frac{1.27}{18.5}\right)\left(1-\frac{0.775}{18.5}\right)=0.89$

Since both two additional double angles (2L $6 \times 3 \frac{1}{2} \times 3 / 8$ and $\left.2 \mathrm{~L} 6 \times 4 \times 9 / 16\right)$ shown in Figure 5 satisfy the condition of $w \leq\left(L_{1}-L_{2}\right) / 2$, the $U$ values for both of them can be computed using Eq. 5 . The results are summarized in Table 3.

Table 1. Shear Lag Factors Derived from the AISC Specification

\begin{tabular}{|c|c|c|c|}
\hline \multicolumn{5}{|c|}{$U_{\text {AISC }}=U_{O E}=1-\frac{\bar{x}}{L}$} \\
\hline LLBB Double Angles & $2 \mathrm{~L} 4 \times 3 \times 3 / 8$ & $2 \mathrm{~L} 6 \times 3 \frac{1}{1} / \times^{3} / 8$ & $2 \mathrm{~L} 6 \times 4 \times 9 / 16$ \\
\hline Shear lag factors $U_{\text {AISC }\left(l_{1}\right)}$ & 0.96 & 0.97 & 0.96 \\
\hline Shear lag factors $U_{\text {AISC (avg) }}$ & 0.94 & 0.96 & 0.95 \\
\hline Shear lag factors $U_{\text {AISC }\left(l_{2}\right)}$ & 0.91 & 0.94 & 0.92 \\
\hline
\end{tabular}

Notes: $L=l_{1}$ for the computation of $U_{\operatorname{AISC}\left(l_{1}\right)}$

$L=\frac{l_{1}+l_{2}}{2}$ for the computation of $U_{\text {AISC(avg) }}$

$L=l_{2}$ for the computation of $U_{\text {AISC }\left(l_{2}\right)}$ 
Table 2. Shear Lag Factors Derived from Fortney and Thornton

\begin{tabular}{|c|c|c|c|}
\hline \multicolumn{4}{|c|}{$U_{F \& T}=U_{C E} U_{O E}=\left(\frac{1}{1+\frac{1}{3}\left(\frac{w}{L}\right)^{2}}\right)\left(1-\frac{\bar{x}}{L}\right)$} \\
\hline $\begin{array}{c}\text { LLBB Double } \\
\text { Angles }\end{array}$ & $2 \mathrm{~L} 4 \times 3 \times 3 / 8$ & $2 \mathrm{~L} 6 \times 31 / 2 \times 3 / 8$ & $2 \mathrm{~L} 6 \times 4 \times 9 / 16$ \\
\hline Shear lag factors $U_{F \& T}$ & 0.92 & 0.93 & 0.92 \\
\hline
\end{tabular}

Note: $L=\frac{l_{1}+l_{2}}{2}$ for the computation of $U_{F \& T}$

Table 3. Shear Lag Factors Derived from the Newly Proposed Formula

\begin{tabular}{|c|c|c|c|}
\hline \multicolumn{4}{|c|}{$U_{\text {New }}=U_{C E} U_{O E}=\left(1-\frac{\bar{y}}{l_{1}}\right)\left(1-\frac{\bar{x}}{l_{1}}\right)$} \\
\hline LLBB Double Angles & $2 \mathrm{~L} 4 \times 3 \times 3 / 8$ & $2 \mathrm{~L} 6 \times 3 \frac{1}{1} \times^{3} / 8$ & $2 \mathrm{~L} 6 \times 4 \times 9 / 16$ \\
\hline Shear lag factors $U_{N e w}$ & 0.89 & 0.89 & 0.89 \\
\hline
\end{tabular}

\section{COMPUTATION OF SHEAR LAG FACTORS USING THE FINITE ELEMENT METHOD}

The finite element method using three-dimensional solid elements and nonlinear static analyses accounting for combined material and geometric nonlinearities are conducted in this work to verify the accuracy of the newly proposed procedure. Figure 6 illustrates the typical length of the tension angles and the applied tensile stress to be used for the construction of the computer models for the finite element analyses using the computer software NISA (NISA [15]).

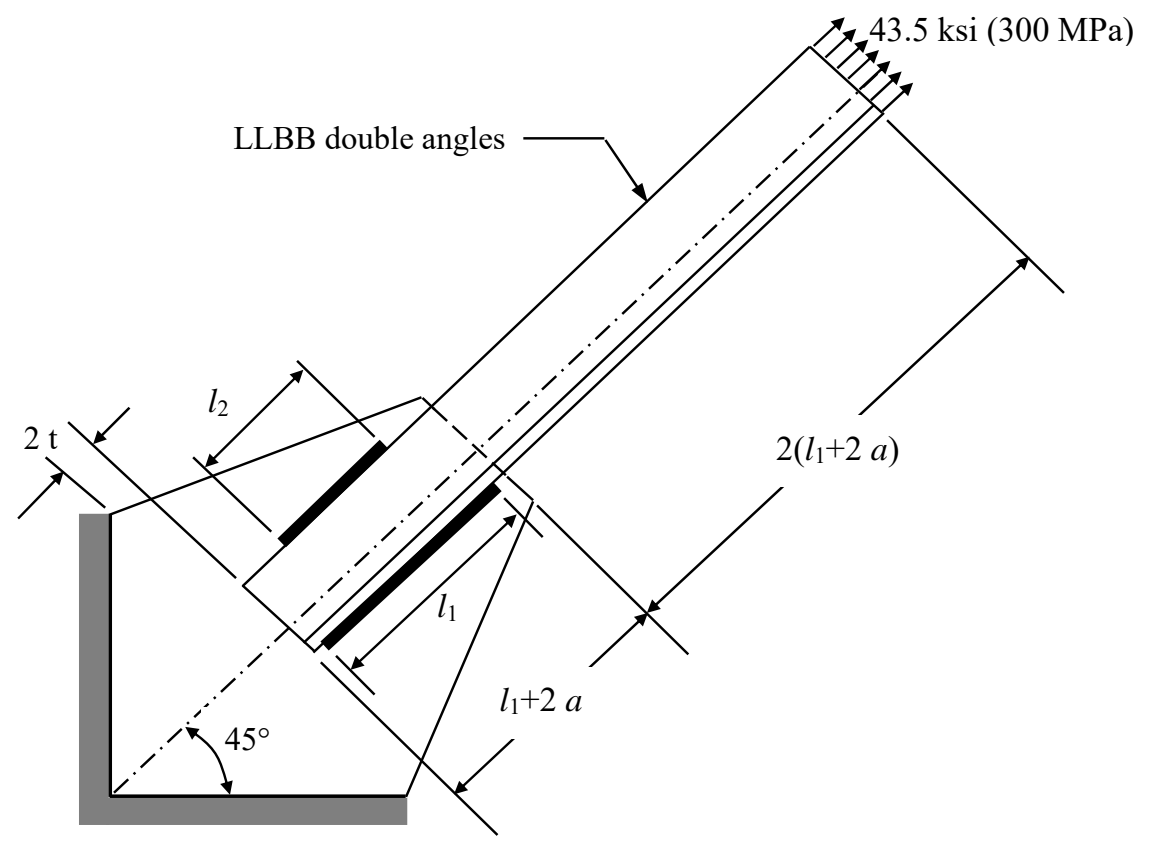

Notes: $\mathrm{t}=$ Plate thickness; $a=$ Weld size; $l_{1}=$ Long weld length; and $l_{2}=$ Short weld length

Figure 6. Typical Length of the Tension Angles and the Applied Tensile Stress at the $100^{\text {th }}$ Time Step 
The computer models for the finite element analyses are composed of numerous 8-node hexahedron and 6-node wedge elements. The material properties of the tension angles are: Modulus of elasticity $=29 \times 10^{6} \mathrm{psi}(200,000 \mathrm{MPa})$ and Poisson's ratio $=0.3$. The analyses account for material nonlinearities based on the elastic, piecewise linear hardening true stress-strain curve, as shown in Figure 7 (derived from Salmon and Johnson [16]) for the A36 steel for tension angles and the elastic, linear hardening, true stress-strain, as shown in Figure 8 (derived from the Lincoln Electric Company [17]) for the E7018 electrode for the longitudinal fillet welds. Therefore, the true stress of $68.73 \mathrm{ksi}(474 \mathrm{MPa})$ and its corresponding strain of 0.1697 , as shown in Figure 7 , are derived from the engineering stress of $58 \mathrm{ksi}(400 \mathrm{MPa})$ (which is the ultimate tensile stress of A36 steel) and its corresponding strain of 0.185 .

A pseudo time of 100 has been used for the time span, which is equivalent to load increments or steps from zero to $\phi_{t} F_{u}$. Note that $F_{u}$ is the ultimate tensile stress of the tension member. Also note that since the first-principal stress is related to fracturing (Cook and Young [18]), there is a critical time step at which the true maximum first-principal stress in the tension angles is closest to 68.73 $\mathrm{ksi}\left(474 \mathrm{MPa}\right.$ ) (the true ultimate tensile stress). Assuming the $\mathrm{i}^{\text {th }}$ time step is the critical time step, the allowable applied tensile load at the free end of the tension angles can thus be determined as follows:

Allowable applied tensile load $=\phi_{t}\left(F_{u}\right)\left(A_{g}\right)\left[\left(i^{\text {th }}\right.\right.$ time step $) /(100$ time steps $\left.)\right]$

Note that $\phi_{t} F_{u}=0.75 \times 58 \mathrm{ksi}=43.5 \mathrm{ksi}(300 \mathrm{MPa})$ for A36 steel is used as the applied tensile stress at the $100^{\text {th }}$ time step as shown in Figure 6. Also, $A_{g}$ is the gross area of the cross-section of the tension member.

Since $A_{n}=A_{g}$ for welded tension members, Eq. 9 is then derived from Eqs. 7 and 8:

$U=\left(\mathrm{i}^{\text {th }}\right.$ time step $) /(100$ time steps $)$

where $U$ is the shear lag factor and the $\mathrm{i}^{\text {th }}$ time step is the critical time step.

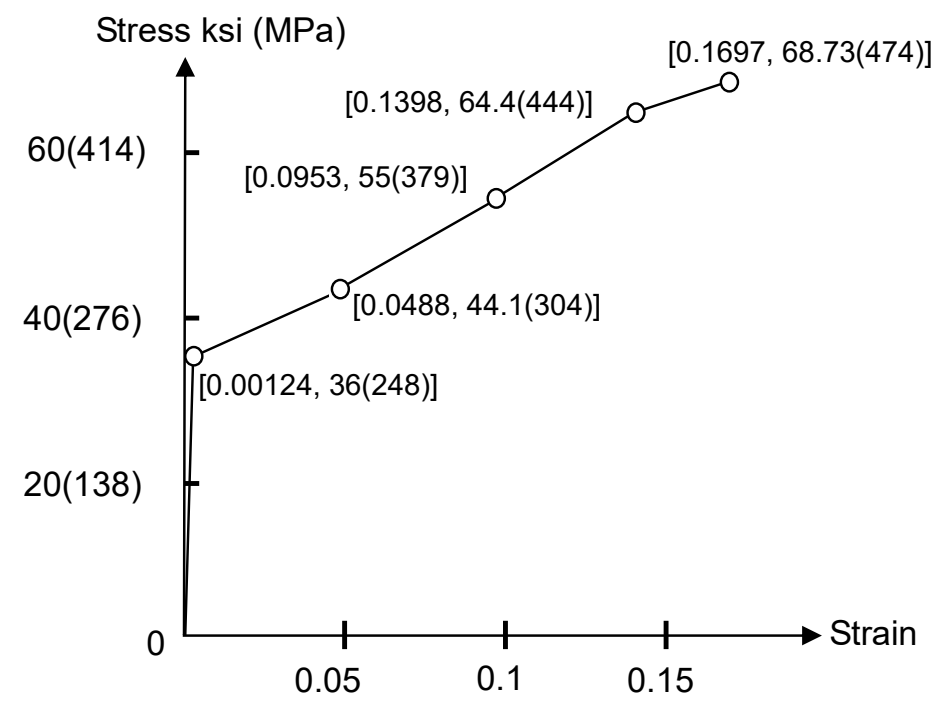

Figure 7. Elastic, Piecewise Linear Hardening, True Stress-Strain Curve for ASTM A36 Steel 


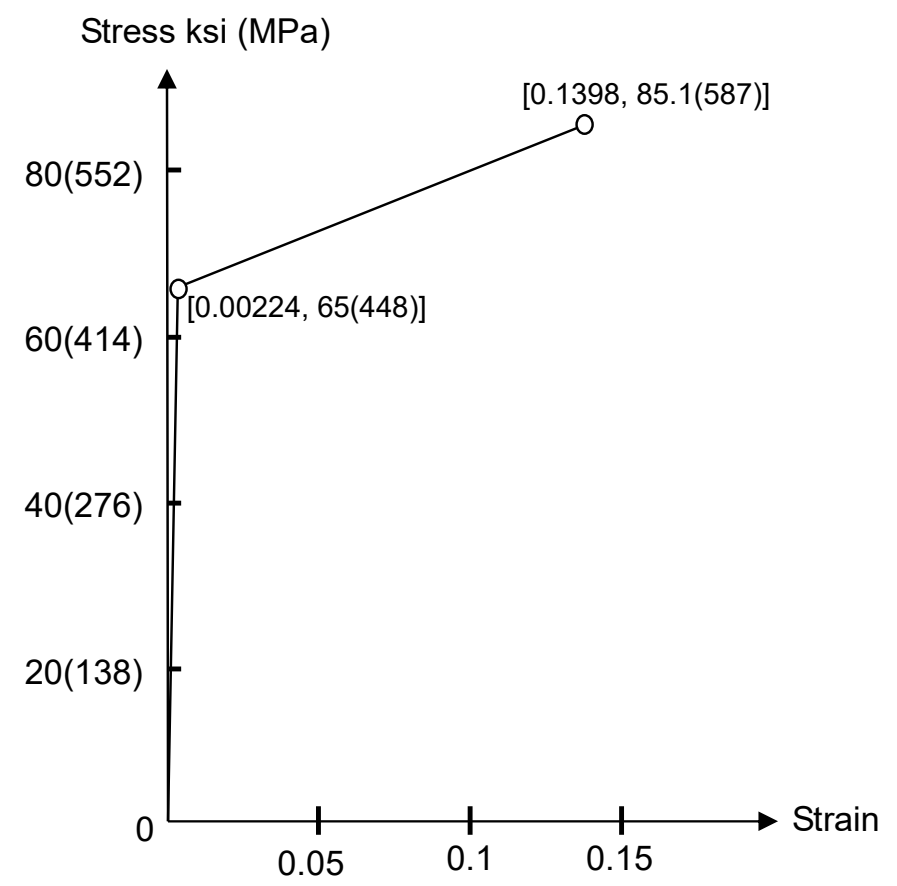

Figure 8. Elastic, Linear Hardening, True Stress-Strain Curve for E7018 Electrode

The results of the finite element analysis for the double angles $2 \mathrm{~L} 4 \times 3 \times 3 / 8$ are shown in Figures 9 , 10,11 , and 12. Figure 9 illustrates that at the $90^{\text {th }}$ time step, the maximum first-principal stress reaches $68.84 \mathrm{ksi}(475 \mathrm{MPa})$ [which is closest to the true ultimate tensile strength of $68.73 \mathrm{ksi}$ (474 $\mathrm{MPa})$ ] at the cross-sectional area of the double angles close to the free end of the gusset plate. Therefore, the $90^{\text {th }}$ time step is the critical time step for the $2 \mathrm{~L} 4 \times 3 \times 3 / 8$ tension member. Furthermore, from Eq. 9, one has $U=90 / 100=0.90$ for the $2 \mathrm{~L} 4 \times 3 \times 3 / 8$ tension member. Figure 10 is a view from the side of the long weld, which illustrates the contour lines of the maximum shear stress distribution at the critical time step for the $2 \mathrm{~L} 4 \times 3 \times 3 / 8$ tension member. The approximate $45^{\circ}$ contour lines of the shear stress distribution at the end of the outstanding leg validate the out-of-plane shear lag effect on the outstanding leg shown in Figure 1. Figure 11 is an overhead view of the contour lines of the maximum shear stress distribution at the critical time step for the $2 \mathrm{~L} 4 \times 3 \times 3 / 8$ tension member. The approximate $45^{\circ}$ contour lines of the shear stress distribution at the end of the connected leg also validate the in-plane shear lag effect on the connected leg shown in Figure 2. Figure 12 illustrates the combined in-plane and out-of-plane shear lag effects on the tension angles.

The results of the finite element analysis for the two additional double angles of different sizes $\left(2 \mathrm{~L} 6 \times 3 \frac{1}{2} \times{ }^{3} / 8\right.$ and $2 \mathrm{~L} 6 \times 4 \times 9 / 16$ shown in Figure 5) are shown in Figures 13 and 14, respectively. Both the figures (Figures 13 and 14) illustrate that at the $90^{\text {th }}$ time step, the maximum first-principal stress reaches a critical magnitude [which is closest to the true ultimate tensile strength of $68.73 \mathrm{ksi}$ $(474 \mathrm{MPa})]$ at the cross-sectional area of the double angles close to the free end of the gusset plate. Therefore, the $90^{\text {th }}$ time step is the critical time step for the $2 \mathrm{~L} 6 \times 3 \frac{1}{2} \times \times^{3 / 8}$ and $2 \mathrm{~L} 6 \times 4 \times 9 / 16$ tension members. The $U$ values for all the double tension angles determined using the finite element analysis approach are summarized in Table 4. 


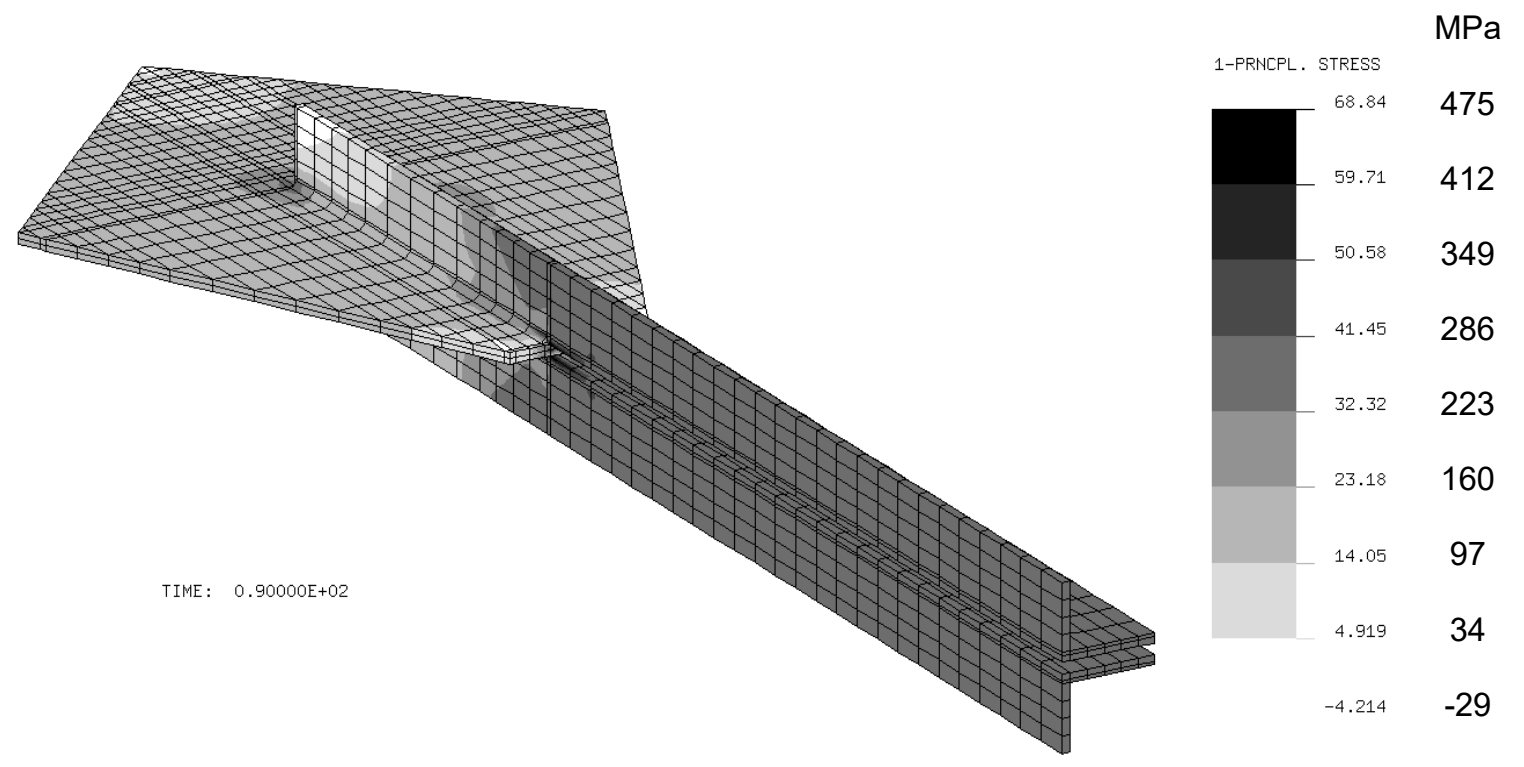

Figure 9. The First-Principal Stress Distribution at the Critical Time Step for the $2 \mathrm{~L} 4 \times 3 \times 3 / 8$ Tension Member

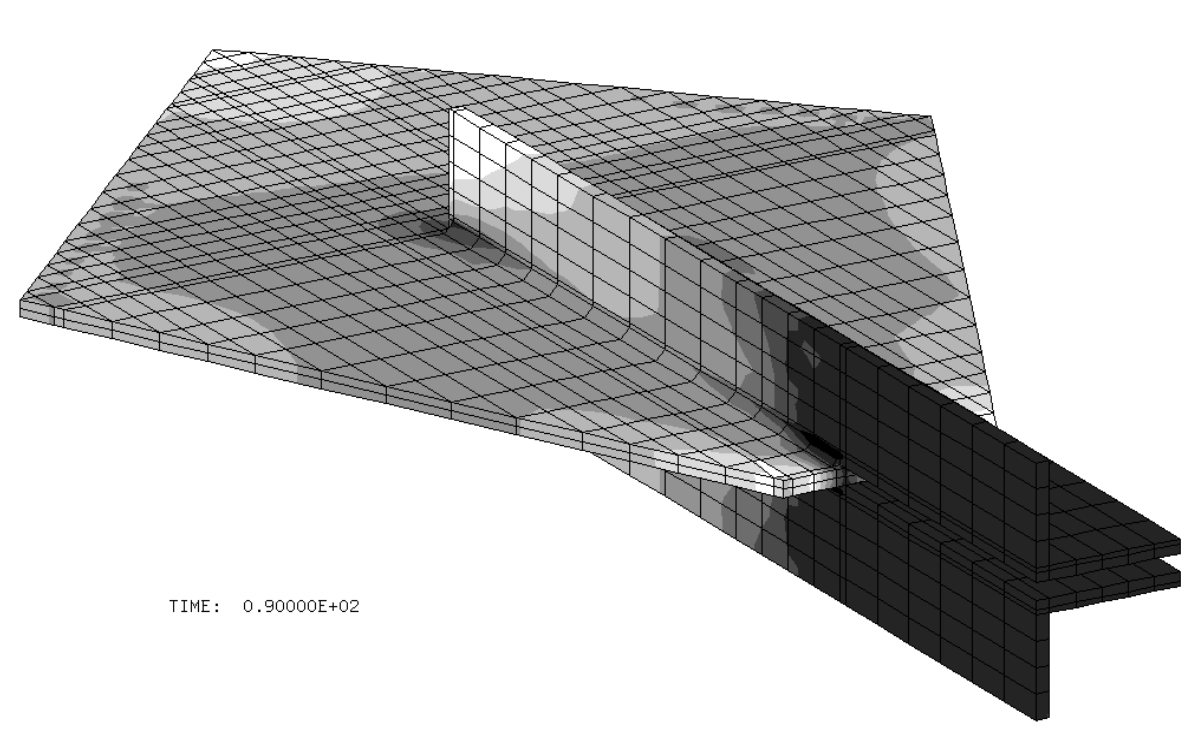

Figure 10. The Maximum Shear Stress Distribution at the Critical Time Step for the $2 \mathrm{~L} 4 \times 3 \times 3 / 8$ Tension Member (a View from the Side of the Long Weld) 


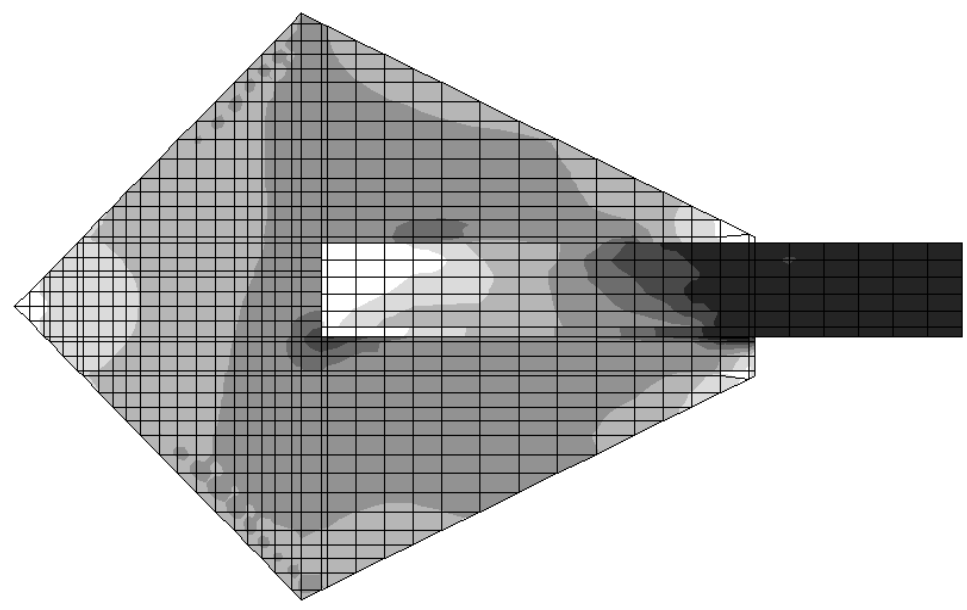

Figure 11. The Maximum Shear Stress Distribution at the Critical Time Step for the $2 \mathrm{~L} 4 \times 3 \times 3 / 8$ Tension Member (an Overhead View)

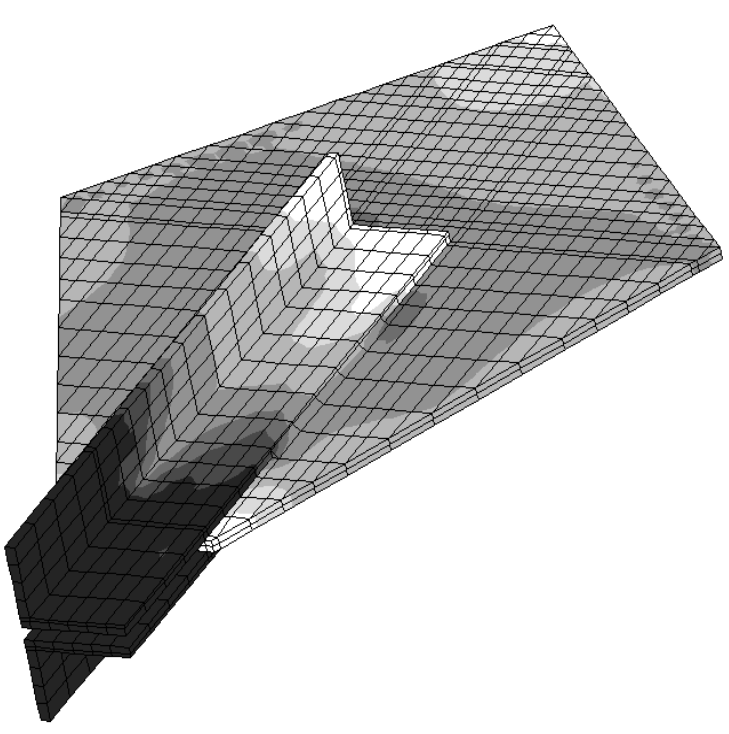

MAX. SHEAR STRS.

$\mathrm{MPa}$

[ $24.75 \quad 171$

$-21.67 \quad 149$

128

107

86

64

43

22

$0.1028 \quad 1$

TIME: $\quad 0.90000 \mathrm{E}+02$

Figure 12. The Maximum Shear Stress Distribution at the Critical Time Step for the $2 \mathrm{~L} 4 \times 3 \times 3 / 8$ Tension Member (a View from the Side of the Short Weld) 

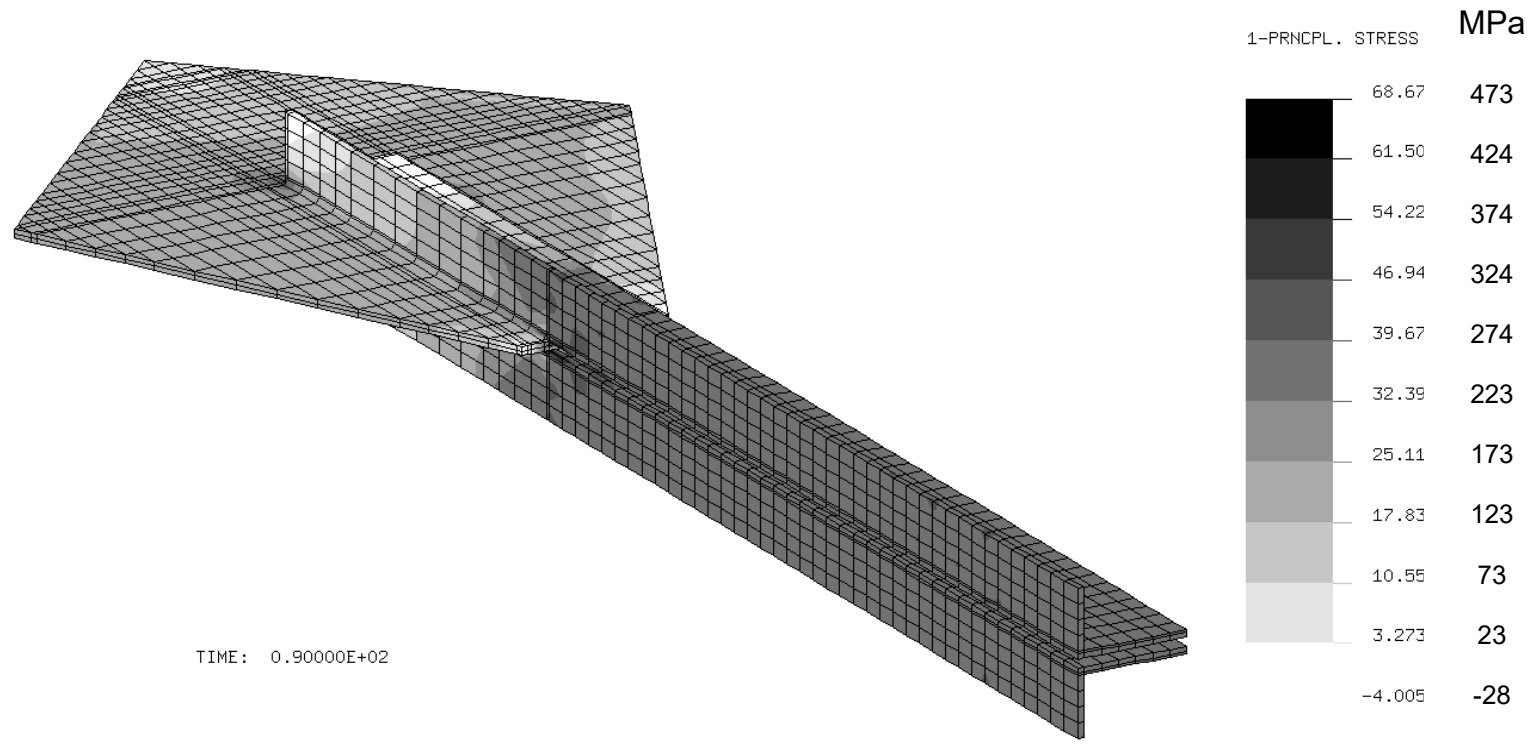

Figure 13. The First-Principal Stress Distribution at the Critical Time Step for the $2 \mathrm{~L} 6 \times 3 \frac{1}{1} \times^{3} / 8$ Tension Member

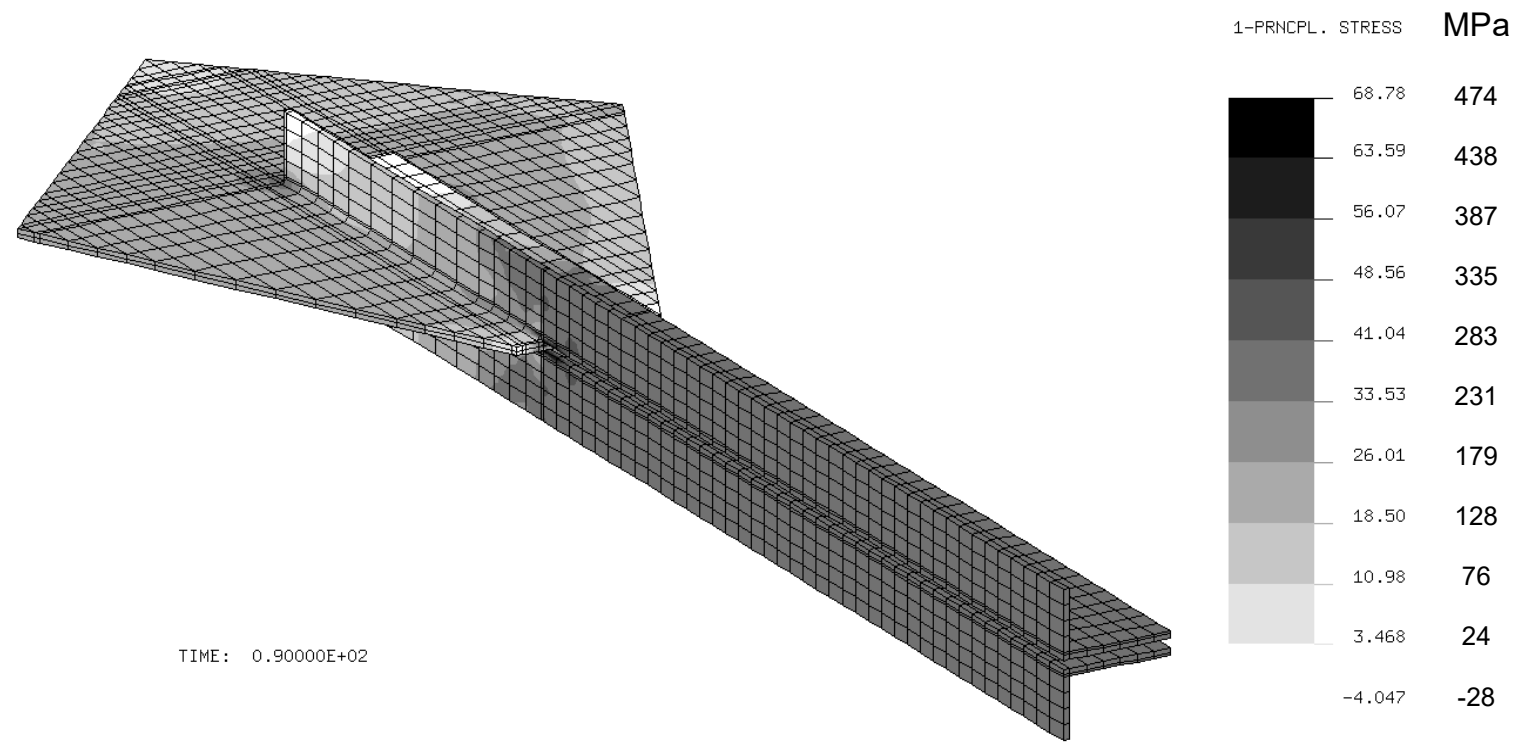

Figure 14. The First-Principal Stress Distribution at the Critical Time Step for the $2 \mathrm{~L} 6 \times 4 \times 9 / 16$ Tension Member 
Table 4. Shear Lag Factors Derived from the Finite Element Analysis Approach

\begin{tabular}{|c|c|c|c|}
\hline LLBB Double Angles & $2 \mathrm{~L} 4 \times 3 \times 3 / 8$ & $2 \mathrm{~L} 6 \times 3 \frac{1}{2} \times 3 / 8$ & $2 \mathrm{~L} 6 \times 4 \times 9 / 16$ \\
\hline Shear lag factors $U_{F E A}$ & 0.90 & 0.90 & 0.90 \\
\hline
\end{tabular}

A summary of the shear lag factors $(U)$ determined using various approaches is graphically shown in Figure 15. This figure combines the results obtained from Tables 1 through 4. Figure 15 shows that among all the approaches, the newly proposed approach gives the results closest to those obtained using the Finite Element Analysis approach.

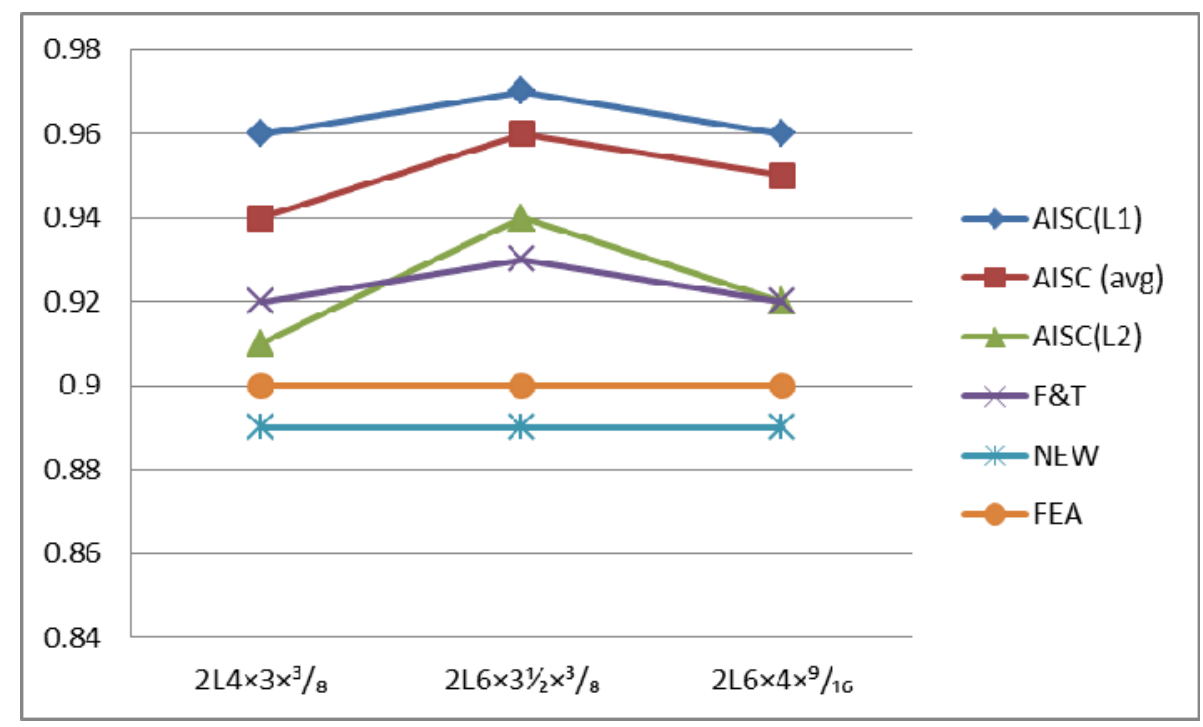

Figure 15. A Summary of the Shear Lag Factors (U) Determined Using Various Approaches

\section{CONCLUSIONS}

When a tension angle is subjected to cyclic loading, which results in repeated stress variations, it is preferable to use two longitudinal welds of unequal length to ensure the welds' centroid will coincide with the centroid of the angle so that the transmitted tensile forces will be balanced about the neutral axis of the angle. The unequal-length longitudinal welds, however, are not addressed by the current AISC Specification for the determination of the shear lag factor for tension members other than plates and Hollow Structural Sections (HSS). In addition, the current AISC Specification neglects the in-plane shear lag effect for the determination of the shear lag factors for tension members other than plates and HSS. A new procedure for the computation of shear lag factors accounting for combined in-plane and out-of-plane shear lag effects on unequal-length longitudinal welded angles is proposed in this work. The finite element method using three-dimensional solid elements and nonlinear static analyses accounting for combined material and geometric nonlinearities are conducted in this work to verify the accuracy of the proposed procedure. This work concludes that among all the approaches discussed in this paper, the newly proposed approach gives the results closest to those obtained using the Finite Element Analysis approach. However, the newly proposed approach can only be applied when $\left(l_{1}-l_{2}\right) / 2 \geq w$, where $\left(l_{1}-l_{2}\right) / 2$ is the indented length at both ends of the short weld, in which $l_{1}$ is the length of the long weld and $l_{2}$ is the length of the short weld, and $w$ is the width of the in-plane welded leg of the angle. 


\section{REFERENCES}

[1] Easterling, W.S. and Gonzalez Giroux, L., "Shear Lag Effects in Steel Tension Members", Engineering Journal, American Institute of Steel Construction, $3^{\text {rd }}$ Quarter, 1993, Vol. 30, pp. 77-89.

[2] AISC, "Specification for the Design, Fabrication and Erection of Structural Steel for Buildings”, American Institute of Steel Construction, Inc., Chicago, IL., 1978.

[3] AISC, "Specification for Structural Steel Buildings-Load and Resistance Factor Design”, American Institute of Steel Construction, Inc., Chicago, IL., 1986.

[4] AISC, "Specification for Structural Steel Buildings-Allowable Stress Design and Plastic Design”, American Institute of Steel Construction, Inc., Chicago, IL., 1989.

[5] AISC, "LRFD Specification for Structural Steel Buildings", American Institute of Steel Construction, Inc., Chicago, IL., 1993.

[6] AISC, "LRFD Specification for Structural Steel Buildings", American Institute of Steel Construction, Inc., Chicago, IL., 1999.

[7] AISC, "Specification for Structural Steel Buildings", American Institute of Steel Construction, Inc., Chicago, IL., 2005.

[8] AISC, "Specification for Structural Steel Buildings", American Institute of Steel Construction, Inc., Chicago, IL., 2010.

[9] Geschwindner, L.F., "Unified Design of Steel Structures”, John Wiley \& Sons, Inc., Upper Hoboken, N.J., 2008.

[10] Fortney, P.J. and Thornton, W.A., "Recommendations for Shear Lag Factors for Longitudinally-Welded Tension Members”, Engineering Journal, American Institute of Steel Construction, $1^{\text {st }}$ Quarter, 2012, pp. 11-32.

[11] Astaneh-Asl, A., "Seismic Behavior and Design of Gusset Plates," Steel Tips Report, Structural Steel Educational Council, Moraga, CA., 1998.

[12] AISC, "Seismic Provisions for Structural Steel Buildings", American Institute of Steel Construction, Inc., Chicago, IL., 2005.

[13] AISC, "Steel Construction Manual", 14 $4^{\text {th }}$ Edition, American Institute of Steel Construction, Inc., Chicago, IL., 2011.

[14] Whitmore, R.E., "Experimental Investigation of Stresses in Gusset Plates", Bulletin No. 16, Engineering Experiment Station, Univ. of Tennessee, TN., 1952.

[15] NISA, “NISA User's Manual”, the Cranes Software, Inc., Troy, MI, 2005.

[16] Salmon, C.G., Johnson, J.E. and Malhas F.A., "Steel Structures, Design and Behavior", 5 Ed., Pearson Prentice Hall, Upper Saddle River, N.J., 2009.

[17] The Lincoln Electric Company, "The Procedure Handbook of Arc Welding”, 13 ${ }^{\text {th }}$ Ed., The Lincoln Electric Company, Cleveland, OH., 1994.

[18] Cook, R.D. and Young, W.C., “Advanced Mechanics of Materials”, Macmillan Publishing Company, New York, N.Y., 1985. 